\title{
6. Republic of Ireland: from Celtic tiger to recession victim
}

\author{
Adam Masters
}

\section{Boom to bust}

Ireland is being battered by international storms the like of which this generation has never seen. But I am saying this to the Irish people-if we work together as a team we can ensure that we have a prosperous future for ourselves, our children and future generations on this island. (Cowen 2009a)

The case of Ireland presents a distinctive experience of a nation's response to the financial crisis. There are, of course, marked similarities with other countries covered in this volume, such as Ireland having a small open economy like New Zealand or membership of the European Union like the United Kingdom. The contextual similarities are, however, far outweighed by differences. Ireland's economy had been built up in the 'Celtic tiger' years on foreign investment and high-tech industry. On the back of these external inputs, the boom years generated bloated domestic finance and real-estate markets. The good times also resulted in a disproportionate expansion of the public sector and an expectation by government that the financial cornucopia would always bestow its manna on the Emerald Isle.

The Irish political leadership first acknowledged the impact of the global financial crisis on Ireland after a sharp fall in government revenue in July 2008. The revenue drop was linked to a downturn in the building industry and housing market, higher food and fuel prices and international financial market turbulence' (Hurley 2008b). Before July, Irish authorities had viewed the turbulence in financial markets as a problem linked to the sub-prime crisis in the United States and the toxic debt instruments associated with poor lending practices by US banks (O'Brien 2008:18). During the next nine months, the impact of the crisis on Ireland became increasingly pronounced as it manifested within the domestic economy.

The key manifestations of the financial crisis in the Irish economy were driven by external and internal factors. External factors included the liquidity crisis triggered by the financial turmoil, which in turn severely impacted on the domestic banking sector. The Irish banks, although not directly exposed to the US sub-prime mortgage market, had lent heavily to property developers, thereby 
inflating values and creating Ireland's own real-estate bubble. Some of these causal factors had been years in the making; others emerged as a result of the crisis, driven by the economic downturn.

Three key public figures responsible for leading Ireland during this period were the Taoiseach (Prime Minister) Brian Cowen, his Minister for Finance Brian Lenihan, and John Hurley Governor of the Central Bank and Financial Services Authority (CBFSA). Cowen and Lenihan came to these roles in May 2008 after the former Taoiseach Bertie Ahern, stood down. Cowen had been Ahern's Minister for Finance and Lenihan previously held the position of Justice Minister. Hurley had held the position of CBFSA Governor since 2002 (Mitchell 2008). This chapter examines, through the lens of the crisis exploitation framework presented in Chapter 2, these three leaders' attempts to manage and frame the global financial crisis as it manifested within Ireland.

\section{Box 6.1 Ireland's financial crisis trajectory, July 2008 - March 2009}

8 July 20o8: After the Exchequer reports an expected shortfall in government revenue of $€ 3$ billion, the new Taoiseach (and former Finance Minister), Brian Cowen, announces a number of new budgetary measures decided on by the government in response to the 'emerging financial pressures'. The measures trigger their own crisis, with a backlash against proposed cuts to pensioners' medical benefits.

19-20 September: The Irish Times reports that Minister for Finance, Brian Lenihan, is prepared to review the government system of guaranteeing 90 per cent of deposits up to a limit of $€ 20,000$ amid calls for this limit to be raised. The next day, the Irish Government moves to secure the deposits in Irish banks to prevent a run on them. The $€ 20,000$ guarantee is increased to $€ 100,000$.

25 September: Ireland is officially the first EU member state to slip into recession.

3o September: Finance Minister Lenihan presents the Credit Institutions (Protection) Bill 2008 to the Dáil (the Irish national parliament). The bill enables the government to take a stake in any financial institution that receives financial support. It also incorporates an 'insurance premium' of 0.2 per cent of deposits over the two years it is in effect. This could amount to $€ 1$ billion in additional revenue to the government in return for a guarantee of more than $€ 400$ billion. The institutions being offered the protection of the guarantee are Allied Irish Bank, Bank of Ireland, Anglo Irish Bank, Irish Life \& Permanent, Irish Nationwide Building Society and Educational Building Society. 
8 October: The CBFSA reduces the interest rate by 50 basis points.

I5 October: The budget is brought forward. Cowen outlines the measures to achieve savings, including additional government borrowing, reduction in public services and raising taxes. Cowen also incorporates an agenda of public service reform.

26 November: The Taoiseach announces measures of reform within the public sector.

5 December: The open, export and service-driven economy of Ireland has nosedived, pushing the government's five-year projected deficit up to about $€ 12.5$ billion. The Finance Minister, indicating the budget position is worse than expected, announces stimulus borrowings, further review of public sector spending and the establishment of the Special Group on Public Service Numbers and Expenditure Programmes. Much of this is overshadowed by a separate crisis related to an outbreak of foot and mouth disease in Irish swine, which occurred just before the Christmas season when hams were in high demand.

I8 December: The Taoiseach announces and releases Building Ireland's Smart Economy: A framework for sustainable economic renewal. The announcement and release of the framework appear to be the result of a long process predating the global financial crisis. The framework is, however, absorbed into the government's reaction to the global financial crisis and linked to the future policy direction for development in Ireland.

I9 December: Seán FitzPatrick, chairman of the Anglo Irish Bank (AIB), resigns. He had been temporarily transferring $€ 87$ million in loans to another institution before the fiscal year's end to avoid disclosure of their existence to shareholders - a practice that had been occurring for eight years. The other institution is believed to be the Irish Nationwide Building Society. The chief executive of AIB resigns several hours later. In response, Finance Minister Lenihan announces plans to recapitalise AIB and the Bank of Ireland, take effective control of AIB and clear out the remaining board members.

9 January 2009: Patrick Neary, chief executive of the Irish Financial Services Regulatory Authority, resigns after allegations that his staff first learned in January 2008 that FitzPatrick had been transferring loans.

28 January: Cowen, speaking in the Dáil, indicates the crisis in Ireland has developed further. A five-year shortfall of $€ 15$ billion has been identified. Cowen says measures, further to those already announced, will be necessary. A new policy is also announced: A Pact for Solidarity and Economic Renewal. This is intended to involve social partners 
(unions, employers) in the solutions and garner political support for future measures.

3 February: The Taoiseach delivers a statement to the Dáil detailing the fiscal and budgetary measures to be taken in 2009/10 to rein in borrowing and reduce expenditure. The unions (social partners) do not agree with the plan, but the government intends to go ahead regardless. The measures include cuts to child care, reduction in overseas aid, reduction in public service pay and delays in agreed pay rises.

I9 February: Finance Minister Lenihan presents the second stage reading of the Financial Emergency Measures in the Public Interest Bill 2009.

Io March: CBFSA Governor Hurley, who has agreed to stay on in his role post-retirement age, claims in response to questions from the Committee on Economic Regulatory Affairs that the government had ignored his many warnings about the state of the Irish economy.

24 March: The Minister for Finance meets with two government-appointed board members for the Irish Nationwide Building Society (INBS) over recent disclosures in relation to the remuneration of the CEO of INBS, which requires further investigation.

\section{Methodological considerations}

It is safe to say in Ireland there is no shortage of speech material from the Taoiseach or the Minister for Finance relating directly or indirectly to the financial crisis. Four key speech acts of each leader were therefore selected for their relationship to key events or the level of public response, rather than the amount of content relating to the case at hand. Examples of key speeches not analysed were Finance Minister Lenihan's speeches in the Dáil introducing the Financial Emergency Measures Bill (Lenihan 2009b). Although rich in crisis rhetoric, the speeches did not introduce new key measures or draw significant media response.

Selection of key speech acts was also limited to those available on the official web sites of the leaders. Although there were media references to speech acts that were not on the web sites, these were discounted from analysis for three reasons. First, the references in the media could be interpreted as vague, referring to what 'the Taoiseach said this week' with no pinpoint reference. Second, the volume of speech material available via the media, even limited to three outlets, was prohibitively large. Finally, leaders must take full ownership of what was posted on an official web site and its provenance should not be disputed.

In analysing the domestic media's response to the Irish leadership with respect to the global financial crisis, two daily newspapers, the Irish Independent and 
the Irish Times, and one weekly, the Sunday Business Post, were selected. Selection of the daily newspapers was based primarily on their position as leading Irish dailies, with the highest and second-highest circulation, respectively. The Sunday Business Post was selected on the basis of the quality of analysis and depth of the articles it published. Although the Sunday Business Post did not have the highest circulation for Irish Sunday papers, its focus on financial and economic activity was considered relevant for this case study.

After the selection of the speeches for analysis, searches were conducted in the chosen newspapers for the week after the speech act. Articles were scanned for relevance to the speech act or the related event. Articles selected for analysis were coded using a three-level scale (agreement, disagreement, neutral/no comment) in relation to four analytical categories: leaders' framing of the severity and the causality of the crisis and support for proposed policies and for the leader. These results were then considered in relation to the crisis-exploitation framework of Chapter 2 to determine the manner with which, and how successfully, these three leaders were able to frame and manage the crisis in Ireland.

\section{Crisis development and elite rhetoric in Ireland}

\section{April 2008: Governor Hurley's trouble-on-the-horizon speech}

Governor Hurley's address to the Institute of Auditors on 18 April 2008 was a measured speech designed to provide reassurances that there was nothing wrong with the fundamentals of the Irish economy, but that trouble was on the horizon. Entitled 'Recent issues in financial stability', the speech explained the developing crisis in terms of the turbulence in the international financial markets, which had persisted longer than many had predicted. Hurley spoke of future outcomes that could 'manifest itself in terms of banking crises and recessions and can be very costly for any economy'. He also noted the greater than anticipated challenges ahead for the Irish economy in 2008. In a more positive vein, however, he listed the 'skilled workforce, flexible labour market, moderate taxation, business friendly regulatory environment and [Ireland's] sound fiscal position' along with the economy's ability to 'absorb adverse shocks' as reasons for confidence in the future.

Blame for the turbulence in global financial markets was attributed to the effects of the US sub-prime crisis and the toxic debt instruments backed by US mortgages. The CBFSA Governor believed that there was little direct exposure by Irish banks to these instruments - once again underpinning the overall strength of the Irish economy. The only domestic factor cited was attributed to a 'marked decline in house-building'. All of these were exogenous to the CBFSA and there was no acceptance of responsibility in this speech. Hurley limited the 
management role of the CBFSA, in terms of its response, to 'monitor[ing] the situation very closely' and participation in international attempts at the EU level to understand the origin of the events in the global markets.

As if to underscore the lack of interest in the doings of the CBFSA Governor, only a single article was published in the three main newspapers referring to Hurley's speech. The article reported that Citigroup (which at the time had 2000 employees in Ireland) was sacking 9000 employees globally. No job losses were announced in Ireland and the journalist duly noted Hurley's comment that the CBFSA and the financial regulator 'regularly stress-tested the Irish banking sector and found that it can weather a significant slowdown' (Carswell 2008a).

\section{July 2008: Finance Minister Lenihan's mixed message}

In July 2008, Irish political leaders did not acknowledge any significant impact of the global financial crisis on the Irish economy. 'Our remarkable economic progress has not been reversed overnight,' the Finance Minister asserted in his budget speech. As his statement evolved, however, he did signal the need for change in the government's fiscal approach. 'If we do not act now, the situation facing us for 2009 will be more difficult and the action needed more urgent'. The urgency that he conveyed was explained by a shortfall in government revenue of $€ 3$ billion resulting from expenditure running 11 per cent ahead and due to higher unemployment.

To manage the shortfall, Lenihan announced the government's intent not to implement planned pay increases for ministers and senior public servants. In doing this, the Finance Minister acknowledged a responsibility for government to act and lead the way in making sacrifices without taking any blame for developments in the economy. The expected savings from the cutbacks were to total $€ 440$ million in 2008 and $€ 1$ billion in 2009. Towards the end of his statement, Lenihan asserted that the government would stand by its choices in regard to the programs and investments of the previous 11 years in which his party had been in power.

\begin{tabular}{|l|l|l|l|l|}
\hline & Severity & Causality & $\begin{array}{l}\text { Proposed } \\
\text { policy }\end{array}$ & $\begin{array}{l}\text { Support for } \\
\text { speaker }\end{array}$ \\
\hline Agrees & 18 & 13 & 9 & 7 \\
\hline Disagrees & 1 & 2 & 19 & 18 \\
\hline $\begin{array}{l}\text { No comment/ } \\
\text { neutral }\end{array}$ & 12 & 16 & 3 & 6 \\
\hline
\end{tabular}

\section{Table 6.1 Media response to Lenihan's 8 July 2008 speech}

The response to Lenihan's announcement of budget cuts was mixed (Table 6.1). Of the articles analysed, only one disputed the severity of the situation, arguing 
that 'it isn't Armageddon' as this announcement allegedly had implied (Irish Times 2008a:15). Lenihan successfully conveyed the causality, which was reflected by only two articles disagreeing with him and pointing instead to past policies of Lenihan's government. While there was general agreement on severity and causality, there was greater opposition to the proposed policies (that is, cuts to spending) and little support for the government that was driving them.

\section{July 2008: Governor Hurley's moderation}

The timing of the launch of the CBFSA Annual Report coincided with speeches by the Taoiseach (not analysed) and the Finance Minister (see above). Governor Hurley remained restrained. In explaining the Irish economic situation, Hurley again pointed to the slowdown in the housing sector as a causal factor. He added a new factor: the fall in the share price of the Irish banks. Hurley repeated reassurances that the Irish banks had little to no direct exposure to the US sub-prime crisis, which was still perceived as the main threat to Ireland's economy.

For Hurley, international turbulence in the financial markets was attributed to downturns in real estate in major economies as well the steep rise in food and fuel prices. In turn, higher commodity prices were both cause and effect of the escalation of the financial problems. The devaluation of the pound against the euro had caused consumers to cross to Northern Ireland or the United Kingdom to take advantage of better exchange rates, resulting in an outflow of capital from the Irish economy. With so many exogenous factors available, there was no acceptance of blame. The only management strategy offered by Hurley was the slight increase in interest rates - a matter for the European Central Bank (ECB), not the CBFSA.

\begin{tabular}{|l|l|l|l|l|}
\hline & Severity & Causality & $\begin{array}{l}\text { Proposed } \\
\text { policy }\end{array}$ & $\begin{array}{l}\text { Support for } \\
\text { speaker }\end{array}$ \\
\hline Agrees & 5 & 7 & 5 & 1 \\
\hline Disagrees & 2 & & 1 & 6 \\
\hline $\begin{array}{l}\text { No comment/ } \\
\text { neutral }\end{array}$ & & & 1 & 6 \\
\hline
\end{tabular}

Table 6.2 Media response to Hurley's 10 July 2008 speech

The reserved language of the CBFSA Governor did not resonate with all journalists reporting on the launch of the Annual Report. Some argued the severity of the downturn was higher than Hurley was letting on. In the Sunday Business Post, there was an acknowledgment that the CBFSA often forecast market contractions, however, this was often buried in the fine print of the Annual Report rather than as part of the public statement from the governor (Curran 2008). The Irish Independent listed many of the global indicators that 
had impacted on Ireland and noted that Hurley, and the CBFSA, 'were not nearly as pessimistic' (Irish Independent 2008a). Nonetheless, all analysed reports agreed with the causes Hurley had identified as producing the darker economic outlook.

With respect to his recommendations on inflationary and fiscal control, commentary was heavily in Hurley's favour. His warnings of too much interference in the markets were accepted, along with the broader government objective of spending cuts announced by the Minister for Finance. Comparing this speech with Lenihan's above, Hurley received approval from the financial press whereas Lenihan did not (cf. Table 6.1). A possible explanation might be found in the authorship of the policy being attributed more to the politicians than to the CBFSA Governor, who was seen to be acting as an instrument of the government's policy.

\section{October 2008: Taoiseach Cowen offering deposit guarantees}

In a speech to the CBI-IBEC Joint Business Council Dinner at Trinity College, the Taoiseach left his audience in little doubt about the scale and seriousness of the global financial crisis in Ireland: 'We live in perilous times...if we do not make the right [choices] it will have catastrophic consequences for the future prospects of our economy...nobody will be immune from the pain'. Through the use of unequivocal language, Cowen set the crisis in terms that were by this time familiar to his audience and had been for a number of months.

The speech followed a number of meetings and an announcement that the government would guarantee deposits in Irish banks up to $€ 100,000$. While that decision had been well received in the banking sector, at the time of Cowen's speech at Trinity College, legislation had just been passed to give substance to the announcement. Cowen needed a degree of popular support to shore up support for the new measure, taken unilaterally by the government, the shock waves of which had reverberated through the rest of Europe and beyond. His crisis rhetoric of 'right choices' as opposed to 'catastrophic consequences' was a reference to this recent legislative action.

In accounting for the impact of the crisis on Ireland, Cowen was brief: 'we are an open economy'. This followed a more detailed coverage of what had happened: a collapse in the housing market, 'turbulence in international financial markets, exchange rate shifts and rapidly rising oil prices', which combined to result in a $€ 6.5$ billion shortfall in government revenue. There was no acknowledgment of any responsibility, even though Cowen had been Finance Minister for a number of years before his elevation to Taoiseach. Blame was attributed to the vaguely exogenous factor of greed, although greed 'has not been absent in Ireland'. 


\begin{tabular}{|l|l|l|l|l|}
\hline & Severity & Causality & $\begin{array}{l}\text { Proposed } \\
\text { policy }\end{array}$ & $\begin{array}{l}\text { Support for } \\
\text { speaker }\end{array}$ \\
\hline Agrees & 45 & 35 & 24 & 26 \\
\hline Disagrees & & 5 & 13 & 12 \\
\hline $\begin{array}{l}\text { No comment/ } \\
\text { neutral }\end{array}$ & 4 & 9 & 12 & 11 \\
\hline
\end{tabular}

\section{Table 6.3 Media response to Cowen's 2 October 2008 speech}

As Table 6.3 illustrates, the majority of articles from the week after Cowen's Trinity College address supported his assertion that the root cause of the local banking crisis had been greed, the collapse in the housing market and the global financial turmoil. There was a higher level of agreement on the severity of the crisis. The proposal to protect depositors up to $€ 100,000$ was supported in just less than half the commentary, with one-quarter disagreeing and a similar number making no commitment either way. Those who disagreed were concerned primarily with the risk to the national economy posed by the guarantee (Kelly 2008:16) or whether it was in line with EU arrangements (Smyth 2008:8).

The Taoiseach's efforts to frame the banking crisis in a way that supported his Fianna Fáil Government were relatively successful. Only one-quarter of the articles analysed reflected a lack of support for the national leader. The strongest support came from other European news media. Germany's Frankfurter Allgemeine Zeitung praised the Irish Government: 'By calming citizens and securing bank financing, the guarantee should achieve its aim of avoiding forced bank nationalisation' (Irish Times 2008b). Media praise was leavened, however, by criticism of the guarantee by EU leaders such as Germany's Angela Merkel and UK Prime Minister, Gordon Brown (Collins and Carswell 2008:1). The strongest criticism was directed against Cowen in the letters to the editor of the Irish Times, questioning the fiscal and economic policies from when he had been the Finance Minister (Irish Times 2008c).

\section{October 2008: Governor Hurley's support for the deposit guarantee}

By October 2008, the continuing drama in Ireland's banks finally drove the CBFSA Governor to use crisis rhetoric. Nonetheless, in his statement to support government moves to guarantee bank deposits for the six major domestic banks, Hurley maintained his reserved manner and used the specific word 'crisis' only once. He was more explicit when describing the urgency of 'events [which] came to a head last Monday evening when the supply of funding... was seriously threatened' and as a result 'decisive action to protect the stability of the economy... was needed'. The reason the crisis had manifested in such an acute 
manner for Hurley was the 'unprecedented shortage of liquidity in financial markets', and any solution needed to target that problem directly.

Hurley 'had to inform the Minister that the risks to financial stability were becoming unacceptably high with knock-on effects for the wider economy'. As a result of this advice, the government had decided to guarantee depositors and lenders to Irish banks, thereby protecting the stability of the Irish financial system. The legislation for the guarantee had passed the day before Hurley's speech. While not accepting responsibility for causing the crisis, Hurley and the government accepted the responsibility for making key and critical decisions to meet the crisis head-on.

\begin{tabular}{|l|l|l|l|l|}
\hline & Severity & Causality & $\begin{array}{l}\text { Proposed } \\
\text { policy }\end{array}$ & $\begin{array}{l}\text { Support for } \\
\text { speaker }\end{array}$ \\
\hline Agrees & 9 & 8 & 8 & 6 \\
\hline Disagrees & & & & \\
\hline $\begin{array}{l}\text { No comment/ } \\
\text { neutral }\end{array}$ & 1 & 2 & 2 & 4 \\
\hline
\end{tabular}

\section{Table 6.4 Media response to Hurley's 3 October 2008 speech}

Response to Hurley's speech was found within the major media coverage of the banking guarantee (Table 6.4). As with Cowen's speech at the same time (see above), his assessment of the severity and causes of the crisis leading up to the guarantee was not questioned. There was, however, a major difference in the responses to the politician and to the banker. Hurley received proportionally much greater support for himself and the policy proposals than did Cowen. This was because articles that mentioned Hurley analysed the economic and fiscal ramifications of the guarantee in greater detail, rather than focusing on the political results. Four of the 10 articles analysed in response to this speech were also used to analyse response to Cowen's first speech act (Carswell 2008b:8; Carswell et al. 2008:1; Hennessy 2008:9; Irish Independent 2008c).

Hurley's popularity also stemmed from his rapid response to one bank's attempt to exploit the guarantee. After a rapid investigation, the CBFSA and financial regulator issued a $€ 50,000$ fine to the Irish Nationwide Building Society (INBS) for 'touting'. A senior employee of INBS (who was also the son of the chief executive) had sent an email to potential customers. The email claimed the INBS was 'the safest place in Europe for deposits and money in INBS bond accounts was guaranteed regardless of the size of the deposit' (Irish Independent 2008b, 2008e). The positive windfall for the governor from the swift action by the CBFSA and the financial regulator was reinforced by a biographical piece on Hurley reflecting on his long public service career as he approached retirement (Mitchell 2008). Hurley's role as a statutorily independent public servant 
minimised his use of crisis rhetoric and buffered him somewhat from opinionated coverage.

\section{October 2008: the Taoiseach's reform agenda}

In his budget statement, Cowen utilised the crisis as a vehicle to push through public service, welfare and education reforms. Public sector reform had been high on Cowen's agenda since taking office as Taoiseach, when he announced the outcomes of an Organisation for Economic Cooperation and Development (OECD) review of the Irish Public Service. Using the language of crisis, Cowen framed the crisis as being 'on a scale last seen in the 1930s'. The proposed level of reform by his government was justified because 'unprecedented times call for unprecedented measures'. Direct action was necessary as 'it is tempting' during difficult times 'to batten down the hatches and wait until the storm is over' - a statement contrived to leave the audience morally obliged to follow the government's lead.

The reason given for the big impact of the global crisis in Ireland was once again its open economy, with decreasing exports hurting government revenue. In this budget, however, the Taoiseach announced measures to manage revenue shortfalls that, had it not been a 'crisis' situation, would have had little chance of being supported. Reductions to pensioners' medical benefits and child benefits were to be supplemented by restructuring of tax benefits for pension contributions. One of the major initiatives to manage the crisis would be the implementation of a public sector reform agenda. In an extension of his early strategy of leading by example, Cowen announced that government ministers and departmental heads would take a voluntary 10 per cent pay cut. The only responsibility Cowen acknowledged was not for the economic crisis, but for the previous high levels of growth.

\begin{tabular}{|l|l|l|l|l|}
\hline & Severity & Causality & $\begin{array}{l}\text { Proposed } \\
\text { policy }\end{array}$ & $\begin{array}{l}\text { Support for } \\
\text { speaker }\end{array}$ \\
\hline Agrees & 21 & 7 & 4 & 6 \\
\hline Disagrees & & 4 & 39 & 38 \\
\hline $\begin{array}{l}\text { No comment/ } \\
\text { neutral }\end{array}$ & 24 & 34 & 2 & 1 \\
\hline
\end{tabular}

\section{Table 6.5 Media response to Cowen's 15 October 2008 speech}

Media reaction to the budget was very negative towards Cowen and the government. In the first week, the majority of media coverage focused on the changes to pensioners' medical benefits. Of the 45 articles analysed, 31 focused on the pensioner medical card debacle. While it made up a relatively small portion of the overall budget ( $€ 100$ million out of a health budget of $€ 15$ billion), the backlash caused Cowen and his government to 'do a U-turn in respect of 
this measure' (Irish Independent 2008g). Less than half of the coverage acknowledged the severity of the crisis in their commentary; the remainder made no comment on it at all. Cowen's causality claims were also largely ignored. The four articles that disagreed on causality blamed the past policies of Cowen's Fianna Fáil Government.

Cowen was unable to fully exploit the global financial crisis and pass all his announced budget cuts. The relatively minor financial return from cutting pensioners' health benefits resulted in a political crisis within Fiánna Fail, with government members rebelling (Irish Independent 2008f) and ruptures with independent parliamentarians (McGee 2008:7). Overwhelmingly, the response was negative, with only one opinion piece offering any support to the government's actions (Irish Times 2008e).

\section{December 2008: Lenihan's reform salesmanship}

'We are in very difficult times' was a clear public acknowledgment made by the Finance Minister about the deteriorating condition of the government's fiscal position. In a statement on the economy delivered to the Seanad Éirann (The Senate) in early December, Lenihan explained that 'a major gap has emerged between spending levels and tax receipts' resulting in a projected government deficit of $€ 3.5$ billion for 2008 and $€ 4.7$ billion for 2009. The cause of the consistent slide in revenue rested with the downturn in the domestic housing sector and the 'major deterioration in the global economic environment...traced to...sub-prime mortgage debt'.

To manage the budget shortfall, Lenihan introduced a range of measures to review spending in the public sector. In doing so, he appeared to make a conscious and careful effort to use language that would not inflame resistance to the foreshadowed changes. Lenihan asserted that 'everybody in this room [the Séanad] is a public servant' and 'the kind of demonisation of the Public Service that has featured in public debate...including political parties' had been deplorable. This linguistic move shifted the blame for any perceived attack on the public sector to his political opponents. Reforms outlined by Lenihan also focused on job preservation and support for the unemployed through social services and access to education and training.

\begin{tabular}{|l|l|l|l|l|}
\hline & Severity & Causality & $\begin{array}{l}\text { Proposed } \\
\text { policy }\end{array}$ & $\begin{array}{l}\text { Support for } \\
\text { speaker }\end{array}$ \\
\hline Agrees & 16 & 12 & 5 & 4 \\
\hline Disagrees & & 2 & 10 & 11 \\
\hline $\begin{array}{l}\text { No comment/ } \\
\text { neutral }\end{array}$ & 2 & 4 & 3 & 3 \\
\hline
\end{tabular}

Table 6.6 Media response to Lenihan's 5 December 2008 statement 
Table 6.6 indicates that in December 2008 the government's framing of the severity of the crisis was widely accepted. The public, media, business and unions all shared Lenihan's view. There was also less debate about the causality of manifestations of the global crisis in Ireland. Dispute generally rested on criticism of past government policy, which some said had failed to insulate the Irish economy from the current financial trauma.

Lenihan's use of his 'Statement on the economy' to drive the policy outcomes required to address the global financial crisis was less than successful. The statement was made amid organised protest against government economic and fiscal policy. A demonstration of students organised by the teachers' union brought about 50,000 protesters to the streets of the capital in a strong show of dissatisfaction with the Finance Minister's policies, which translated into a much lower level of support for the government's leadership (Flynn 2008:17). Loss of respect within the Fianna Fáil was also generated by an apparent lack of consultation among party members and accusations of rule by a triumvirate that included Lenihan, Cowen and the Tanaiste (Deputy Prime Minister), Mary Coughlan (Irish Independent 2008i). The difficulties of balancing the budget and the use of the crisis to drive reform were soon to be overshadowed as the banking crisis re-emerged in the New Year.

\section{January 2009: Lenihan's take on AIB nationalisation}

There had been much speculation after the government's deposit guarantee in October 2008 about whether the marker would be called in by the banks as a result of the global financial crisis. In mid January, Lenihan announced that the funding position of the Anglo Irish Bank (AIB) had weakened and 'unacceptable practices that took place within it had caused serious reputational damage' (CBFSA 2009). As a result, the government moved beyond recapitalisation to the 'decisive step of public ownership'. The government decision was to 'safeguard the interests of depositors of Anglo, and the stability of the economy'.

The swift response by the government required a high level of management to ensure that the public purse would not be hit by a further loss. AIB shares were suspended from trade in Ireland and the United Kingdom. Information was made available to shareholders and the public in the form of a question and answer page on relevant government web sites and that of the AIB. With the move to nationalisation, the interests of shareholders became secondary to those of depositors. 'Shares in Anglo will be transferred to [the Minister of Finance, who] will appoint an independent assessor, who will decide the value of the shares and decide what level (if any) of compensation shareholders will get' (It's Your Money 2009).

The share value for AIB had fallen sharply since May 2007-from $€ 17.50$ to $€ 0.22$ (O'Halloran 2009:8). 
The poor share performance had led to calls for the government to inject funds into AIB and hold an extraordinary general meeting (EGM) of shareholders. The government's decision not to bail out AIB and nationalise the bank came the day before the EGM. Nationalisation angered many of the attending shareholders, particularly when it became apparent their shares had become virtually worthless and were to be appropriated by the government (Beesley 2009:9).

\begin{tabular}{|l|l|l|l|l|}
\hline & Severity & Causality & $\begin{array}{l}\text { Proposed } \\
\text { policy }\end{array}$ & $\begin{array}{l}\text { Support for } \\
\text { speaker }\end{array}$ \\
\hline Agrees & 33 & 29 & 10 & 8 \\
\hline Disagrees & & 3 & 23 & 22 \\
\hline $\begin{array}{l}\text { No comment/ } \\
\text { neutral }\end{array}$ & 8 & 9 & 8 & 11 \\
\hline
\end{tabular}

\section{Table 6.7 Media response to Lenihan's 15 January 2009 speech}

Reaction to the nationalisation of a major bank, as seen in Table 6.7, reflected societal awareness of the severity of the financial crisis facing Ireland and an acceptance of the causality. This did not, however, translate into an immediate policy victory for Lenihan in his framing of the crisis, nor did it engender political support. Tracking the tone of media articles through the week reflected an initial stunned media and public response, followed thereafter by a level of anger, particularly from shareholders and taxpayers - the former group likely to lose money in the arrangement and the latter likely to join them (Irish Independent 2009a). When grouped with the variety of opposition parties, there was nearly three times as much opposition to the government's decision to nationalise AIB as there was support. Media reports, however, did not blame the government for the collapse of AIB. Blame was directed at the AIB chairman and board of directors, who in the public's mind were guilty of criminal behaviour $\left(\mathrm{O}^{\prime}\right.$ Toole 2009:14).

Lenihan's credibility as a leader during the global financial crisis was undermined when he was caught out in a radio interview not knowing what the statement posted on the CBFSA web site actually said. According to one commentator, Lenihan 'did not know that the official government response to [the disgraced chairman of AIB] FitzPatrick's gigantic scam on his bank's shareholders was that it was "disappointing"' (O'Toole 2009:14). This was a massive understatement compared with the public and media opinion of the behaviour of the AIB chairman and board of directors. As one letter to the editor phrased it: 'which is the appropriate Government Department to approach for a no-strings-attached, interest-free and fully concealable loan of approximately €87 million?' (Irish Times 2009a:17). 


\section{January 2009: Cowen's crisis plan}

In his statement to the Dáil Éireann, Cowen began by framing the situation as Ireland facing 'the most difficult global economic conditions in seventy years' and 'the most severe financial crisis since the Great Depression'. Once again, the Taoiseach attributed Ireland's economic problems to the openness of the economy, adding 'the sharp appreciation in the value of the Euro' and decline in the demand for Irish exports. Cowen's brevity in naming, explaining and accounting for the crisis was balanced by a detailed plan to manage it.

Cowen reminded his audience that the government had moved 'swiftly [to] introduce a banking guarantee' and had acted to provide support for mortgagees who had fallen behind in payments. The government also 'support[ed] efforts at [an] international level to establish regulatory mechanisms' and what was proportionally Europe's largest capital investment program. Cowen described these actions as having the main goal of 'return[ing] the economy to sustainable growth per [the] Framework for Sustainable Economic Renewal'. The framework was a 105-page plan focused on a 'smart economy' based on research and development, innovation, environmental balance, infrastructure investment and efficiency in the public sector (Department of the Taoiseach 2008). To implement the broader plan, Cowen called for a Pact for Stabilisation, Solidarity and Economic Renewal to be negotiated with the social partners.

Cowen used crisis rhetoric in an attempt to box in the social partners so they would endorse the government's policy agenda. The Taoiseach implied that any failure would rest with the social partners.

\begin{tabular}{|l|l|l|l|l|}
\hline & Severity & Causality & $\begin{array}{l}\text { Proposed } \\
\text { policy }\end{array}$ & $\begin{array}{l}\text { Support for } \\
\text { speaker }\end{array}$ \\
\hline Agrees & 16 & 14 & 6 & 7 \\
\hline Disagrees & & 1 & 10 & 11 \\
\hline $\begin{array}{l}\text { No comment/ } \\
\text { neutral }\end{array}$ & 4 & 5 & 4 & 2 \\
\hline
\end{tabular}

\section{Table 6.8 Media responses to Cowen's 28 January 2009 speech}

There were two key factors influencing public reaction to the Taoiseach's speech. First, there were continuing negotiations to secure $€ 2$ billion in savings with the unions, in their role as social partners. After a long period of industrial harmony supported by economic growth, there was little chance that Cowen would garner the unconditional support of the union leadership for economic measures that directly impacted on union members. The lack of support for Cowen is attributable to the well-reported response of the unions. Second, there was Barack Obama. The American President-Elect's speeches calling for sacrifice in times of economic uncertainty were widely reported. To add to Cowen's woes, 
the media and public drew comparisons between the two leaders and the Irishman was found wanting (Irish Times 2009b:15).

There were calls for the Taoiseach to make a state of the nation address, similar to the US 'State of the Union' address (Devlin 2009). Further comparison found that 'unlike Obama, Cowen [had] no plan. He [had] not had a plan since he started, nor did he have one as Finance Minister' (Arnold 2009). This additional pressure made it increasingly difficult for the Taoiseach to exploit the crisis for policy or political gain.

\section{February 2009: Cowen's break with the social partners}

The breakdown of the social partnership between the government and the unions demonstrated the speed and depth of the impact of the crisis on Ireland. There was less than a week between Cowen's announcement on delivering sustainable economic renewal and securing public finances and his announcement of the Framework for Stabilisation, Social Solidarity and Economic Renewal. With a slight variation on his speech of a week before, Cowen described the situation as 'the most profound global economic crisis in seventy years'. In another push to manage the financial crisis, the government had spent the intervening period engaged in discussions with the social partners that had resulted in the framework. The framework took 'urgent and radical action to restore stability in public finances, to maximise short term economic activity and employment and to improve competitiveness'.

The Taoiseach had tried to manoeuvre the unions into providing support the previous week. As a result of the negotiations, the unions decided they could not agree to the framework, thereby giving Cowen's government a scapegoat should the framework fail. The government took a political risk by taking decisions without backing from one of the major social partners - a break with a key feature of Irish socioeconomic governance since 1987.

The plan to manage the financial crisis was to be a major economic undertaking. With an initial commitment to save $€ 2$ billion and a total of $€ 18.5$ billion in economic adjustments by 2013, it 'represent[ed] a huge political, economic and social challenge for every single person' in Ireland.

\begin{tabular}{|l|l|l|l|l|}
\hline & Severity & Causality & $\begin{array}{l}\text { Proposed } \\
\text { policy }\end{array}$ & $\begin{array}{l}\text { Support for } \\
\text { speaker }\end{array}$ \\
\hline Agrees & 36 & 11 & 18 & 17 \\
\hline Disagrees & & 2 & 21 & 24 \\
\hline $\begin{array}{l}\text { No comment/ } \\
\text { neutral }\end{array}$ & 10 & 33 & 7 & 5 \\
\hline
\end{tabular}

Table 6.9 Media response to Cowen's 3 February 2009 speech 
The reaction to the Taoiseach's announcement of the framework was from a population now feeling the effects of the crisis. While most media reporting agreed with the severity of the crisis in Ireland, there was no commentary on the causal factors. By this stage, however, nearly every speech act by the Taoiseach made reference to the global financial crisis, so there was no need for the media to reinforce what was well known. The two articles that disagreed with the causal factors attributed the blame to the past policies of Cowen's government.

The framework stimulated greater media coverage than the other speeches analysed in this chapter. This was largely due to it marking the collapse of the social partnership arrangement between unions, business and government that had dominated previous decades. The articles that disagreed with the fiscal policies in the framework focused mainly on the union movement's reaction and the foreshadowed industrial action protesting against a new pension levy for public servants (Irish Independent 2009d). Comparing Cowen's speeches (cf. Tables 6.3, 6.5 and 6.8), however, the negative reaction was not as overwhelming as previously experienced. Cowen received support from those who appreciated his direct style of communication and from business and private sector groups (Irish Independent 2009b, 2009c).

\section{February 2009: Lenihan's blame management}

Facing an 'ocean of advice out there about [what] to do', the Minister for Finance laid out a grim message to the Dáil when seeking its support in 'tackling the current economic and fiscal crisis'. Lenihan's statement on economic and spending measures forecast decline in growth, negative export growth and a significant increase in unemployment. These negative factors had resulted in growth in government borrowing to $€ 18$ billion for 2009. The result of these developments had blown out national debt to 45 per cent of gross national product (GNP), with an annual interest bill of ' $€ 4.5$ Billion, or 12 per cent of total tax take'. The government's plan to address this was threefold: first, getting the cost base down; second, keeping 'up the real value of...investment in national productive capacity'; and finally, doing the first two in a fair manner.

A high level of blame management accompanied the tough measures. Lenihan addressed those who 'instead of advancing constructive policies...try to fix the blame and not the problem'. Lenihan then attempted to acknowledge his own culpability while simultaneously transferring it: 'perhaps as a government we were over-ambitious in trying to meet the...demands...for more and better public services when the resources were there'. This statement was immediately followed by the observation that the opposition had never called for 'less spending, lower social welfare increases, higher taxes, more levies' when the government had rolled out its agenda in the good times. Blame was also transferred to the unions, as the social partners could not agree to the 
government's savings regime in the middle of the 'worst crisis in international financial markets in 60 years'.

\begin{tabular}{|l|l|l|l|l|}
\hline & Severity & Causality & $\begin{array}{l}\text { Proposed } \\
\text { policy }\end{array}$ & $\begin{array}{l}\text { Support for } \\
\text { speaker }\end{array}$ \\
\hline Agrees & 15 & 7 & 5 & 6 \\
\hline Disagrees & & & 11 & 10 \\
\hline $\begin{array}{l}\text { No comment/ } \\
\text { neutral }\end{array}$ & 3 & 11 & 2 & 2 \\
\hline
\end{tabular}

\section{Table 6.10 Media response to Lenihan's 4 February 2009 speech}

Lenihan's statement on economic and spending measures was delivered a day after the Taoiseach announced the Framework for Stabilisation, Social Solidarity and Economic Renewal (see above). As a result, much of the commentary on the government's performance was in response to both these speech acts. A little more than half of the media reports reflected the lack of support for the government program - due mainly to the fallout from union opposition to spending cuts and pay reform in the public sector. As the bearer of bad economic tidings and social upheaval, the Finance Minister did not succeed in exploiting the crisis for political gain.

Letters to the editor of the Irish Times provided a snapshot of public opinion. Most reflected the anger within Ireland towards the situation at hand and much of that anger was directed towards the government. This anger went so far as to call for 'senior churchmen or religious leaders [to] come together and issue a joint condemnation of the Government's handling of the economic crisis' (Irish Times 2009c:17). Successful exploitation of the crisis in Ireland was an enormous challenge for the elected politicians, whether in government or opposition.

\section{March 2009: Hurley's blame deflection}

The final speech act analysed in this chapter presented an interesting turnaround for the otherwise staid Governor Hurley. Only two significant speech acts are located on the CBFSA web site after the banking guarantee. Both were to committees of the Oireachtas (Parliament), and it was the second on 10 March to the Committee on Economic Regulatory Affairs that highlighted the change in Hurley's rhetoric. The change was not only in the speech, but in the media response it garnered, particularly in relation to the questions asked of Hurley by committee members after the speech.

The opening of Hurley's statement was rich in the rhetoric of crisis. His economic assessment covered the recent history of the downturn and its development at global, EU and national levels. The global conditions were blamed for making the 'domestic economic situation much worse'. He outlined actions taken by the 
government and the CBFSA, including the provision of liquidity early in the crisis, involvement at EU level to ensure national regulatory action dovetailed with international plans and the actions to nationalise the AIB. After his opening statement, Hurley opened himself and his colleagues to questioning by the committee. The questions were not listed as part of the speech, however, the media reported a large amount of blame transference from the CBFSA Governor to the government for the severity of the crisis (Carswell 2009a:18, 2009b:2; Irish Independent, 2009f, 2009g, 2009h, 2009i, 2009j; McManus 2009:16).

\begin{tabular}{|l|l|l|l|l|}
\hline & Severity & Causality & $\begin{array}{l}\text { Proposed } \\
\text { policy }\end{array}$ & $\begin{array}{l}\text { Support for } \\
\text { speaker }\end{array}$ \\
\hline Agrees & 2 & & & 2 \\
\hline Disagrees & 1 & 1 & & 3 \\
\hline $\begin{array}{l}\text { No comment/ } \\
\text { neutral }\end{array}$ & 6 & 8 & 9 & 4 \\
\hline
\end{tabular}

\section{Table 6.11 Media response to Hurley's 10 March 2009 speech}

Hurley's address to the Oireachtas initially appeared to bemuse the media. Two reasons for his change in rhetoric and entry into the blame game were immediately apparent. First, Hurley had remained on as governor beyond his retirement date to help get Ireland through the global financial crisis (Irish Independent 2009f). This 'post-retirement' sense of complete independence led him to be more 'forthright than is usual for central bankers' (Irish Independent $2009 \mathrm{~g}$ ). Second, Hurley appeared to be defending his own reputation through blame deflection (O'Malley and Duffy 2009:17).

Hurley claimed he had issued numerous warnings regarding the looming peril, which had been ignored by the government; however, this attempted deflection drew criticism from the media. The majority of the articles analysed tended to focus on the man, not the policy. He was variously described as 'gloomy', the 'Central Bank Cassandra' (Irish Independent 2009h) and 'downbeat' (Irish Independent 2009g). One piece described Hurley's attempt to deflect blame as 'handwashing of breathtaking proportions' (McManus 2009:16). Hurley's annual salary was also subjected to media scrutiny after his call for the Irish not to be paid more than their EU counterparts (Carswell 2009a:18). The negativity continued, as the only commentary that discussed Hurley's financial forecasts disagreed with his framing and predicted an even bleaker outlook than the one outlined by the CBFSA (Irish Independent 2009g).

\section{Framing the financial crisis in Ireland: analysis and conclusions}

Initial government attempts to exploit the financial crisis in Ireland were discernable in two key policy moves: reform of the public sector and a push to 
implement major structural change in the way the Irish economy was moving into the future. Within the analytical framework and time frame examined, there was little evidence that these attempts were successful. The broader context of Irish politics and history, however, must be taken into account to allow for a more nuanced view of the findings. The following discussion will examine public sector reform within a historical context and economic reform within a political context, as well as considering some of the unintended consequences of the government's response to the global financial crisis. The chapter will conclude with a comparative analysis of how these polices, in the context of the global financial crisis in Ireland, were framed by the Taoiseach, the Finance Minister and the bank governor.

\section{Public sector reform}

In April 2008, three months before the global financial crisis seriously manifested in Ireland, the Fianna Fáil Government led by Bertie Ahern and with Brian Cowen as Minister for Finance commissioned the OECD to review the operation of the Irish Public Service. A task force was appointed on the day Cowen became Taoiseach with the goal of preparing an implementation plan for the OECD recommendations (Cowen 2008c). The timing of the task force announcement illustrates the political imperative and the importance in Cowen's view of public sector reform. Within a historical context, the Irish public services had grown in the boom years of the 'Celtic tiger' economy. Quite literally, hundreds of departments, agencies and quangos (quasi-non-governmental organisations) developed in the good times and the State could no longer afford them. This growth in the public sector led to a corresponding growth in the level of service provided to and received by the Irish population. Ireland had struggled economically for many years and had been considered one of the 'poor four' —or, more unkindly, 'PIGS' (Portugal, Ireland, Greece and Spain) - of the European Union (Rumford 2002:154). This had changed with the boom economy and there was understandable resistance in the population and the unions to any government move to wind back spending, which would in turn impact on jobs and services. With the downturn in tax revenue, the larger public sector was no longer a sustainable proposition.

The push for public service reform by linking it to the financial crisis was a politically daring attempt to win popular support - as well as support from the social partners, or at least their acceptance of reduced government bureaucracy and service. The announcement to implement the task force reforms fell between the banking guarantee in October 2008 and the December 2008 budget. The timing was designed to foreshadow the cuts the Finance Minister would announce and to prepare the public and social partners-now cognisant of the downturn - for the belt-tightening changes ahead. 


\section{Reform of the Irish economy}

The second major reform pushed by the Fianna Fáil Government was a modernisation of the Irish economy. After the budget in December, the Taoiseach launched the government's Framework for Economic Renewal. The 105-page plan opened with 'Ireland faces challenging economic circumstances but there are also great opportunities on the horizon' (Department of the Taoiseach 2008:Foreword). Economic reform in these circumstances was a case of a type-3 framing stance. The government was laying the groundwork needed to use the opportunity of the crisis to reform the economy. The plan repackaged existing policies with a vision to 're-prioritise the business of Government and to re-focus resources in a manner that will hasten economic renewal' (Department of the Taoiseach 2008:Foreword).

The framework was not well received, being variously described as 'stale reheats' (Irish Independent 2008i), a 'woolly document' (Irish Times 2008f:17), a 'patchwork document' (Lord 2008:9) and a 'lead balloon' (Lucey 2008:15). Most of the criticism focused on the government's attempt to map out a medium and long-term plan for the economy, based on previously announced strategies, while failing to address the immediate necessities of the financial crisis. The framework disappeared almost immediately into the background as the banking crisis resurfaced with the nationalisation of AIB. Furthermore, a different and more pressing crisis was leading public concern: a suspected break-out of foot and mouth disease in Irish piggeries (Irish Independent 2008h). This major export industry was deeply affected in the lead-up to Christmas. Visible in the media was the call for decisive leadership to see the Irish people through the combined crises. Such leadership was glaringly absent, according to the commentators.

The media and the opposition parties both criticised the lengths to which Cowen and Lenihan had gone in order to protect the social partnership while trying to save the economy. The speed with which the global financial crisis manifested in Ireland made the protracted negotiation process not only redundant in the eyes of some commentators, but an economic hazard (Collins 2008:16). Between the crisis in the piggeries and the broad range of political criticism, the economic reform agenda laid out in the framework failed to gain traction. What was not made clear in public statements or action until February 2009 was any acknowledgment that it would be impossible to introduce the necessary reforms or reduce spending levels to save the economy and meet all the needs of the social partners. Decisive, coherent and bold leadership was being called for (McDonough 2009:11). Bold leadership, however, had its own pitfalls.

\section{Unintended consequences}

The Irish Government's handling of the financial crisis triggered a series of unintended consequences with their own political and policy ramifications - for 
example, the backlash over the pensioner medical card discussed in the analysis of the Taoiseach's budget speech of 15 October 2008.

Also in October 2008, the banking guarantee generated its own crisis in the European Union. Questions were raised about whether the Irish Government's actions were strictly legal in terms of the financial arrangements between EU members. The question of legality was itself subjected to its own political intrigues. There had been pressure on Ireland to hold a second referendum on the Lisbon Treaty after the first referendum ended with a 'no' vote. Although concerned about the legality of the Irish banking guarantee, the European Union allegedly did not strongly oppose the move for fear of jeopardising chances of a new Irish referendum (Irish Times 2008b). The Irish Government was also aware that any move to bring the matter of bank guarantees before a European court would take nearly two years and it felt secure in its actions (Irish Independent 2008d; Irish Times 2008d). Nonetheless, the Irish economy and banking sector are inextricably linked to the euro currency and the ECB, and EU membership is an integral part of Irish politics. The opinions from EU member states' news media impacted on the domestic response to particularly the Taoiseach's speeches. As such, the Irish leaders still had to remain cognisant of their nation's position as part of the European Union.

Another unintended consequence of the October 2008 banking guarantee was the nationalisation of the AIB. All the government statements from the time of the guarantee declared that no bank would be nationalised as they were all financially sound. The guarantee was simply to underpin national economic security. This was disputed at the time AIB was nationalised; a prominent economist claimed the government had been warned not to include AIB in the guarantee because of its unstable circumstances (Irish Independent 2009e). This claim led to a political slanging match in the papers over who knew what when, and what was said to whom (Irish Independent 2009e).

Nationalisation of the AIB generated another political crisis over the 'golden circle' - a group of 10 high-level borrowers who were allegedly given loans of $€ 450$ million by AIB to buy shares in AIB. Details of this arrangement came out after the nationalisation of the bank. There were allegations that Cowen knew of the arrangement and the names of the borrowers and this led to substantial political pressure on Cowen and Lenihan to 'name names' (Collins and Hennessy 2008:1; O'Regan 2009:8).

\section{Rhetorical consistency}

The number of sub-crises generated in Ireland in the wake of the global financial crisis necessitated a level of unity among the political leadership, which will now be examined. With parliamentary elections not due until 2012, this chapter's period of analysis was situated within a relatively safe political period for Cowen 
and Lenihan. This safety translated into consistency between the political leaders in addressing the global financial crisis. When comparing the Taoiseach and Finance Minister with the Governor of the CBFSA, however, there were discernable differences in the type of rhetoric used in framing the global financial crisis. Whereas Cowen and Lenihan had a political game to play, the more secure Hurley stuck closer to the facts at hand without recourse to crisis language.

In marked contrast with the elected leaders, the Governor of the CBFSA was initially more reserved in his public statements. His role had been primarily to maintain a sense of calm and to prevent panic in the markets. It was only when the banking guarantee was announced that Hurley began to use crisis rhetoric, falling in line with Cowen and Lenihan at that time. As noted above, Hurley later attempted to avoid blame by claiming the government had ignored his warnings of financial dangers (Hurley 2009).

The economic drama that manifested in Ireland was primarily the result of exogenous factors that were beyond the control of the Irish Government. Attempts by the opposition to blame the government for the impact of the global financial crisis on the Irish economy were largely ineffectual. As indicated in the above discussion on public sector reform, Fianna Fáil had not been criticised when it was spending the boom-time revenues on public services and infrastructure (Lenihan 2008b). Short of a major revolt within the governing party, there was little chance of leadership change before the 2012 national elections. This left Cowen and Lenihan room to implement some of their medium-term strategies of reforming the public sector and economy.

In terms of the crisis-exploitation framework presented in Chapter 2, the long-time incumbent Fianna Fáil Government somewhat surprisingly emerged as a key advocate of radical policy change. The Taoiseach, Finance Minister and government were the main reformers (the parliamentary opposition were also advocates of changes, albeit different ones). The chief status quo players were found in the unions and among student, pensioner and other interest groups. This produced a stalemate in relation to the pensioner medical card issue and the break between the government and the social partners. As the financial resources of the State contracted, decisive leadership was privileged over political niceties. While the government conceded on the pension card in October 2008, by February 2009, it was prepared to introduce economic plans without the consent of the unions. The Irish Government had gone from policy stalemate to a politically imposed paradigm shift.

In the political game, the Irish Government was not forced to fend off blame for the global financial crisis, but it was subjected to criticism for past fiscal policies. There is little evidence to suggest that the continuing criticism had any serious traction. The majority of commentary accepted that the major causal factors were exogenous and had their roots in the global financial crisis. Critics of past 
policies had trouble concurrently attacking new proposals, as they would appear as mere nay-sayers. This, combined with the remoteness of elections, was a major factor curtailing potential blame games.

\section{References}

Arnold, B. 2009, 'I don't want to be governed by unions or this Taoiseach', Irish Independent, 31 January.

Beesley, A. 2009, 'Cabinet feared bank could soon become insolvent', Irish Times, 17 January, p. 9.

Carswell, S. 2008a, 'Citigroup announces 9,000 job cuts after €3.2bn loss', Irish Times, 19 April, viewed 28 March 2009, $<$ http://www.irishtimes.com/newspaper/frontpage/2008/0419/ 1208468840934_pf.html>

Carswell, S. 2008b, 'Government keen to show strength as it decides on bank fees', Irish Times, 4 October, p. 8.

Carswell, S. 2009a, 'Banks "did not alter behaviour" despite central bank warnings', Irish Times, 11 March, p. 18.

Carswell, S. 2009b, 'EBS takes pain up front with loan write-off', Irish Times, 13 March, p. 2.

Carswell, S., McGee, H. and Beesley, A. 2008, 'Government seeks €2bn from banks for funding guarantees', Irish Times, 4 October, p. 1.

Central Bank and Financial Services Authority (CBFSA) 2009, Minister's statement-Anglo Irish Bank, Press release, 15 January, Central Bank and Financial Services Authority of Ireland, viewed 25 March 2009, $<$ http://www.centralbank.ie/frame_main.asp?pg=nws_curr.asp\&nv= nws_nav.asp>

Collins, S. 2008, 'Air of unreality as plan's long view ignores storm now raging', Irish Times, 19 December, p. 16.

Collins, S. and Carswell, S. 2008, 'Cabinet to finalise details of bank rescue scheme', Irish Times, 7 October, p. 1.

Collins, S. and Hennessy, M. 2008, 'Economic recovery programme to include tax stimulus', Irish Times, 18 December, p. 1

Cowen, B. 2008a, Address by the Taoiseach, Mr Brian Cowen TD, to the CBI-IBEC Joint Business Council Dinner in Trinity College, Dublin, 2 October, Department of the Taoiseach, viewed 28 March 2009, $<$ http://193.178.1.117/index.asp?locID=582\&docID=4031>

Cowen, B. 2008b, Statement on budget 2009, Speech by An Taoiseach, Mr Brian Cowen TD, 15 October, Dáil Éireann, Department of the Taoiseach, 
viewed 27 March 2009,

$<$ http://193.178.1.117/index.asp?locID=582\&docID=4049>

Cowen, B. 2008c, Speech by An Taoiseach, Mr Brian Cowen TD, at the launch of the government's statement on transforming public services, Dublin Castle, 26 November, Department of the Taoiseach, viewed 27 March 2009, <http://193.178.1.117/index.asp?locID=582\&docID=4114>

Cowen, B. 2009a, Delivering sustainable economic renewal and securing our public finances, Statement by the Taoiseach, Mr Brian Cowen TD, Dáil Éireann, 28 January, Department of the Taoiseach, viewed 27 March 2009, <http://www.taoiseach.gov.ie/index.asp?locID=605\&docID=4223>

Cowen, B. 2009b, Taoiseach announces government decision on the implementation of the Framework for Stabilisation, Social Solidarity and Economic Renewal following negotiations with the social partners, 3 February, Department of the Taoiseach, viewed 27 March 2009, <http://www.taoiseach.gov.ie/index.asp?locID=605\&docID=4237>

Curran, R. 2008, 'The inquisitor: how foolproof is the central bank's stress test?', Sunday Business Post, 13 July, viewed 19 April 2009, $<$ http://archives.tcm.ie/businesspost/2008/07/13/story34363.asp>

Department of the Taoiseach 2008, Building Ireland's Smart Economy: A framework for sustainable economic renewal, 18 December, Department of the Taoiseach, viewed 27 March 2009, <http://193.178.1.117/attached_files /BuildingIrelandsSmartEconomy.pdf $>$

Devlin, M. 2009, 'Cowen needs a rallying call to unite the people', Irish Independent, 29 January.

Flynn, S. 2008, 'The budget offended ordinary people and trampled on the aspirations they hold for their own children', Irish Times, 9 December, p. 17.

Hennessy, M. 2008, '24 hours that brought Irish banks back from the brink', Irish Times, 4 October, p. 9.

Hurley, J. 2008a, Recent issues in financial stability, Address to the Institute of Internal Auditors, 18 April, Central Bank and Financial Services Authority of Ireland, viewed 25 March 2009, $<$ http://www.centralbank.ie/frame_main.asp?pg=abt_gove.asp\&nv= abt_nav.asp $>$

Hurley, J. 2008b, Opening statement of Governor John Hurley, Press briefing to mark the publication of the Annual Report of the Central Bank and Financial Services Authority of Ireland, 10 July, Central Bank and Financial Services Authority of Ireland, viewed 25 March 2009, 
Framing the global economic downturn

$<$ http://www.centralbank.ie/frame_main.asp?pg=abt_gove.asp\&nv= abt_nav.asp>

Hurley, J. 2008c, Statement by Governor John Hurley, 3 October, Central Bank and Financial Services Authority of Ireland, viewed, 25 March 2009, $<$ http://www.centralbank.ie/frame_main.asp?pg=abt_gove.asp\&nv= abt_nav.asp>

Hurley, J. 2009, Opening statement by Governor John Hurley to the Joint Oireachtas Committee on Economic Regulatory Affairs, 10 March, Central Bank and Financial Services Authority of Ireland, viewed 18 May 2009, $<$ http://www.centralbank.ie/frame_main.asp?pg=abt_gove.asp\&nv= abt_nav.asp>

Irish Independent 2008a, 'Battered banks get key vote of confidence', Irish Independent, 11 July.

Irish Independent 2008b, 'Building society apologises for using guarantee to lure savers', Irish Independent, 4 October.

Irish Independent 2008c, 'Hoping for calm after the storm', Irish Independent, 4 October.

Irish Independent 2008d, 'Lenihan's destiny will be defined by next two weeks', Irish Independent, 6 October.

Irish Independent 2008e, 'Irish Nationwide fined €50,000 for "touting"', Irish Independent, 8 October.

Irish Independent 2008f, 'Cowen sought loyalty but got only open revolt', Irish Independent, 20 October.

Irish Independent 2008g, 'One shambles after another', Irish Independent, 20 October.

Irish Independent $2008 \mathrm{~h}$, 'Kitt hits out at Cowen over control by trio', Irish Independent, 8 December.

Irish Independent 2008i, 'Rescue blueprint is "100 pages of stale reheats"', Irish Independent, 19 December.

Irish Independent 2009a, 'Nervous taxpayers await the real bill for Anglo', Irish Independent, 17 January.

Irish Independent 2009b, 'Public sector pensions still the biggest perk of the job', Irish Independent, 6 February.

Irish Independent 2009c, 'Brian's mask slips to reveal glimpse of a better leader', Irish Independent, 7 February.

Irish Independent 2009d, 'Pension strikes threaten to cripple country', Irish Independent, 9 February. 
Irish Independent 2009e, 'Neary to face new grilling over bank scandal', Irish Independent, 23 February.

Irish Independent 2009f, 'Banks ignored warnings on lending risks, says governor', Irish Independent 11 March.

Irish Independent 2009g, 'Economy to shrink by more than 6pc, TDs told', Irish Independent, 11 March.

Irish Independent 2009h, 'Shadow of a gunman leads to a sombre mood in House', Irish Independent, 11 March.

Irish Independent 2009i, 'EU may have to 'print' money to survive global crisis', Irish Independent, 11 March.

Irish Independent 2009j, 'How world banking salaries compare', Irish Independent, 12 March.

Irish Times 2008a, 'Real or imagined cutbacks?', Irish Times, 9 July, p. 15.

Irish Times 2008b, 'Eurogroup Chairman rejects European rescue fund', Irish Times, 2 October.

Irish Times 2008c, 'State guarantee to Irish banking system', Irish Times, 3 October, p. 15.

Irish Times 2008d, 'Handling of seismic events was good for Irish politics', Irish Times, 4 October, p. 15.

Irish Times 2008e, 'There must be a return on our trust in the Taoiseach', Irish Times, 21 October, p. 13.

Irish Times 2008f, 'Financial realities still to be faced', Irish Times, 19 December, p. 17.

Irish Times 2009a, 'State takeover of Anglo Irish Bank', Irish Times, 17 January, p. 17.

Irish Times 2009b, 'The need for leadership', Irish Times, 29 January, p. 15.

Irish Times 2009c, 'Facing up to crisis in the public finances', Irish Times, p. 10 February, p. 17.

It's Your Money 2009, 'Anglo Irish Bank Corporation Limited: information for consumers', It's Your Money, 15 January, viewed 25 March 2009, $<$ http://itsyourmoney.ie/index.jsp? $\operatorname{lnID}=93 \& 2 \mathrm{nID}=100 \&$ $3 \mathrm{nID}=153 \& \mathrm{nID}=569 \& \mathrm{aID}=657>$

Kelly, M. 2008, 'Bailout inept and potentially dangerous', Irish Times, 2 October, p. 16.

Lenihan, B. 2008a, Statement by Brian Lenihan TD, Minister for Finance, 8 July, Department of Finance, viewed 28 March 2009, 
Framing the global economic downturn

$<$ http://www.finance.gov.ie/viewdoc.asp?DocID =5370\&CatID $=54$

$\&$ StartDate $=01+$ January $+2008 \& m>$

Lenihan, B. 2008b, Statement on the economy to Seanad Éirann by Minister for Finance, Mr Brian Lenihan TD, 5 December, Department of Finance, viewed 28 March 2009,

$<$ http://www.finance.gov.ie/viewdoc.asp?DocID =5568\&CatID $=54$

$\&$ StartDate $=01+$ January $+2008 \& m>$

Lenihan, B. 2009a, Economic and spending measures, Statement by Minister for Finance, 4 February, Department of Finance, viewed 28 March 2009, $<$ http://www.finance.gov.ie/viewdoc.asp?DocID $=5659 \&$ CatID $=54$ $\&$ StartDate $=1+$ January $+2009 \& m=>$

Lenihan, B. 2009b, Second stage reading: Financial Emergency Measures in the Public Interest Bill 2009, Minister for Finance, Brian Lenihan TD, Dáil Éireann, 19 February, Department of Finance, viewed 28 March 2009, $<$ http://www.finance.gov.ie/viewdoc.asp?DocID =5681 \&CatID $=54$ $\&$ StartDate $=1+$ January $+2009 \& m=p>$

Lord, M. 2008, 'Vision of a smart Ireland leaves most observers perplexed', Irish Times, 19 December, p. 9.

Lucey, B. 2008, 'The government that mistook a blueprint for a recovery plan', Irish Times, 20 December, p. 15.

McDonough, T. 2009, 'Stop bailing out bad banks and build good ones', Irish Times, 24 March, p. 11.

McGee, H. 2008, 'McGrath breaks off deal with Fianna Fáil', Irish Times, 21 October, p. 7.

McManus, J. 2009, 'Governor of Central Bank has raised a few eyebrows', Irish Times, 16 March, p. 16.

Mitchell, S. 2008, 'Bailout broker', Sunday Business Post, 5 October, viewed 19 April 2009, $<$ http://archives.tcm.ie/businesspost/2008/10/05/story36459.asp>

O'Brien, C. 2008, 'US stocks fall on fears banks will be hit by new credit-market losses', Irish Times, 26 January, p. 18.

O'Halloran, B. 2009, 'Anglo board and auditors criticised at EGM, shareholders told Fitzpatrick owed bank a total of $€ 129 \mathrm{~m}$ in 2007', Irish Times, 17 January, p. 8.

O'Malley, E. and Duffy, M. 2009, 'Coping with crisis in public finances', Irish Times, 12 March, p. 17.

O'Regan, M. 2009, 'Cowen denies knowing who received Anglo loans', Irish Times, 18 February, p. 8. 
O'Toole, F. 2009, 'Credibility shredded by mess of Anglo Irish', Irish Times, 20 January, p. 14.

Rumford, C. 2002, The European Union: A political sociology, Blackwell, Oxford. Smyth, J. 2008, 'Commissioner wary of guarantee', Irish Times, 2 October, p. 8. 